\title{
Influence of land use and landscape setting on the ecological status of rivers
}

\author{
J. David Allan
}

School of Natural Resources \& Environment. The University of Michigan.

Ann Arbor, MI USA 48109. dallan@umich.edu

\begin{abstract}
The development of bioassessment methods for lotic ecosystems, combined with advances in geographic information systems and spatial analysis, has resulted in a rapidly expanding literature linking land use to river condition. Such studies provide evidence that declines in forested land and increases in agricultural and urban land frequently are predictors of a degraded state of the habitat and biota. However, further research should address a number of challenges to our current knowledge. Both linear and non-linear relationships have been described, and it will be useful to know when to expect non-linear or threshold responses. Legacy effects, where historical impacts may be stronger than present-day impacts, may be common but can be difficult to recognize. There is ample evidence that landscape factors influence lotic ecosystems across a wide range of spatial scales, but the roles of near-stream vs. larger spatial scales can be difficult to separate. This is part of the larger issue that multiple, interacting factors link landscape change to stream response, and the pathways or mechanisms are rarely identified. Natural and anthropogenic gradients often co-vary, because human activities are most intense in certain landscape settings, making it difficult to determine how much of the variation in stream condition should be attributed to human actions. Finally, because bioassessment methods are intended to detect impairment rather than diagnose cause, it is important to establish mechanisms that more precisely link land-use activities to stream condition, in order to prescribe appropriate restoration action. Future research that combines landscape-stream condition analyses with a basic understanding of the pathways whereby human alteration of landscapes influences river condition can serve the dual function of advancing both the management and the understanding of lotic ecosystems.
\end{abstract}

Keywords: streams, land use, biological assessment, catchment, watershed

\section{RESUMEN}

El desarrollo de métodos de evaluación biológica para ecosistemas lóticos, combinados con los avances en los sistemas de información geográfica y de análisis espacial, han originado un rápido incremento en las publicaciones sobre la relación de los usos del suelo con el estado de los ríos. Tales estudios aportan evidencias de que una disminución en la superficie forestal y un incremento en el suelo agrícola y urbano, frecuentemente suponen una degradación del hábitat y la biota. No obstante, las futuras investigaciones deberían conducir hacia nuevos retos para nuestro actual conocimiento. Se han descrito relaciones tanto lineares como no lineares, por lo que será útil conocer cuando prever respuestas límites o no lineares. Los efectos heredados, donde los impactos históricos pueden ser más fuertes que los actuales, pueden ser comunes pero dificiles de reconocer. Hay una amplia evidencia de que los factores del paisaje influyen en los ecosistemas lóticos en un amplio rango a escala espacial, aunque puede resultar dificil separar los papeles de las escalas espaciales locales vs. grandes escalas. Esto es parte de una cuestión mayor en la que múltiples factores que interaccionan relacionan cambios en el paisaje con las respuestas de los ríos, y donde las vías o mecanismos son raramente identificados. Los gradientes naturales y antropogénicos a menudo covarían, debido a que las actividades humanas son más intensas en determinadas formaciones del paisaje, haciendo dificil determinar que grado de la alteración en las condiciones del río serían debidas a las acciones humanas. Finalmente, ya que los métodos de evaluación biológica están dirigidos a detectar impactos más que a diagnosticar las causas, es importante establecer mecanismos que relacionen de forma más precisa las actividades en los usos del suelo con el estado de los ríos, con el fin de prescribir las actuaciones adecuadas de restauración. La investigación futura que sea capaz de combinar los análisis de las condiciones del paisaje y del río con una interpretación básica de los caminos por los que la alteración humana del paisaje influye en el estado del río, puede servir para la doble función de avanzar tanto en la gestión como en el entendimiento de los ecosistemas lóticos.

Palabras clave: ríos, usos del suelo, evaluación biológica, cuenca hidrográfica, divisoria de aguas. 


\section{THE CATCHMENT APPROACH}

Aquatic ecologists have a long history of incorporating landscape setting into their analyses of freshwater ecosystems. Examples include the early appreciation that lake trophic status was related to the agricultural productivity of surrounding land, longitudinal studies of rivers that recognized the importance of changes in slope and terrestrial vegetation, and the large number of comparative studies that draw insight from differences between ecosystems that are best understood in the context of particular environmental settings (Allan \& Johnson 1997). Rivers are strongly influenced by their surroundings, perhaps most strongly by conditions at the land-water interface (Naiman \& Decamps 1990), but also by the entire catchment. As Hynes (1975) so effectively argued in an early synthesis of landscape-stream interactions, "In every respect, the valley rules the stream." Increasingly today, we are experiencing the negative repercussions of this relationship, as human degradation of landscapes is reflected in the deterioration of stream condition (Naiman et al. 1995).

Studies of biological diversity indicate that many aquatic taxa are amongst the most severely threatened of all animal groups in North America (Master et al. 1998). Fully two-thirds of the mussels, half of the crayfish and onethird of the fishes of North America are threatened and in need of some form of conservation management. Because species-level assessments of aquatic insects are few, it is difficult to substantiate direct biodiversity loss, but numerous studies in North America document changes in aquatic insect assemblages that are evidence of community decline (Karr \& Chu 1999). In Europe, with its long history of human modification of landscapes and river courses, many rivers show evidence of degradation. Ongoing studies, such as El Proyecto Guadalmed, directed by N. Prat and colleagues, are providing an improved understanding of the status of multiple rivers within Spain. Numerous presentations at the Spanish Limnology XI Congress and Iberian Limnology III Congress, June 2002, also document the extent of human impacts to rivers and their various causes.

A large number of stressor sources create altered conditions within river habitats and ultimately contribute to declines in water quality, habitat and biota (Allan \& Flecker 1993, Karr et al. 2000). The primary human activities that serve as stressor sources include stream flow and channel modification, urbanization and residential development, forest management practices, agriculture, mining, and recreation (Bryce et al. 1999). These, in turn, result in varying levels of nutrient enrichment, sedimentation, contamination, habitat deterioration, and altered flow regimes. Non-indigenous species, accidentally or purposefully introduced into new habitats, create nearly irreversible change in the biota, and in many instances one or a few such species almost completely dominate the community in numbers and mass. So many dams and impoundments have been constructed in the USA that in all of the 48 conterminous states, in this large and comparatively young nation, only 42 river segments longer than 200 $\mathrm{km}$ remain free-flowing (Benke 1990). Conflicts between human and ecosystem uses of fresh water have generated heated battles, and these pressures are expected to grow as rising levels of population and affluence collide with finite limits to water supply (Poff et al. 2003). Climate change represents a potentially serious additional threat, but the impacts at this time are only beginning to be identified.

It is noteworthy that many, although not all, of these threats are entirely or partly due to human activities in the landscape, and thus can be quantified from data on land use.

Two developments are responsible for the very rapid growth in studies linking land use to stream condition. The increasing sophistication of bioassessment tools, motivated by the need to assess status and trends of rivers, has led to many published river assessments. The advent of the field of landscape ecology, combined with ready availability of land use/land cover data, the development of geographic informa- 
tion systems for mapping and analysis, and new developments in spatial statistics, have resulted in an expanding literature pertaining to rivers and their catchments including many efforts to connect landscape measures to stream assessments. This has important implications for our ability to improve science-based conservation and management of rivers and streams, through catchment-scale analysis of rivers and their landscapes.

In brief, the catchment approach to the management of river ecosystems can be conceived of in four steps: identification of a land-water unit, assessment of the status or "health" of the river, identification of the stressors that influence river status, and the development of management or restoration plans, grounded in good ecological science, to reverse or mitigate impacts.

\section{ASSESSMENT}

At the center of this enterprise are the separate efforts to quantify the state of the landscape and the status of the river and stream. Linking landscape to stream status has for the most part involved statistical approaches, and often these are multivariate statistical approaches due to the many variables that can be quantified for both the catchment and the stream. At present, such analyses often lack any explicit consideration of mechanisms, and this is a weakness that future researchers should address.

\section{Landscape Status}

The field of landscape ecology has developed greatly over the past decade, and now provides a wide variety of methods and metrics for assessing the status of the landscape. Land use/cover information is the most easily obtained and most widely used in ecological analyses. Ideally, data reflect either land use (e.g., agriculture) or land cover (e.g., orchard, row crop). However, often these are not quantified in a way that makes them easy to separate, and so reference to use/cover, or simply cover, is common.
Widely used metrics of land use/cover include proportion of catchment area in agriculture, forest, wetlands, urban, etc. The proportion of these categories in a riparian buffer strip that extends $10 \mathrm{~m}, 100 \mathrm{~m}$, or some other lateral distance on each side of the stream may be particularly useful because near-stream activities can be especially detrimental to stream condition, and riparian buffers can be an effective management practice (Gregory et al. 1991, Lowrance et al. 1997). Some recent attempts have been made to ascertain the optimal distance and configuration of buffer measurements (Schuft 1999), although application of such methods requires that underlying data be of high spatial resolution, which may not be common.

Landscape pattern metrics now are widely used, due to available software such as FRAGSTATS (McGarigal \& Marks 1994), which can readily calculate hundreds of pattern metrics. These metrics provide quantification of the patchiness or fragmentation of the landscape, based on such metrics as patch density, mean patch size, interspersion, dominance of a single patch type, shape, edge measurements, and more. These can be estimated at the landscape level, irrespective of patch type, or at the class level, such as the patchiness of forests within a catchment. Usually these metrics are not practical for riparian buffers (if landscape patches are larger than the width of the buffer), because the boundary of the lateral buffer frequently cuts through existing fragments, altering their size and shape.

Landscape ecologists explore spatial pattern under the premise that spatial pattern can be linked to ecological processes, and will provide insights beyond what can be learned from proportional land use/cover (Forman \& Godron 1986). This expectation remains largely untested.

Finally, when landscape data are available from two different time periods, it is possible to determine extent and location of change, such as increasing urbanization. This approach also is largely untested in catchment analyses, although Harding et al. (1998, discussed below) provide a striking example of its effectiveness. 


\section{Biological Metrics}

A number of different approaches to biological assessment are presently in use. Some of this diversity reflects the preferences of individual scientists and may be manifested in a de facto standard approach at the national level. While some convergence will occur over time, it is probable that each of these approaches can adequately distinguish highly altered from relatively unimpacted sites, and all experience some difficulties in distinguishing small increments of disturbance.

Indicator species were one of the first approaches used in the assessment of stream condition based on the biota. Although this approach received less attention after about 1970, the Hilsenhoff Biotic Index (Hilsenhoff 1987), which sums scores based on tolerance to organic pollution, is widely used and is in essence a cumulative indicator organism approach. In Europe, the BMWP (developed by the Biological Monitoring Working Party in the UK, Hellawell 1986) and its adaptation to Spain (the BMWP', Alba-Tercedor \& Sánchez-Ortega 1988) function similarly. The multimetric index approach is perhaps best known from the Index of Biotic Integrity (IBI) developed first for fish assemblages in the Midwestern USA (Karr 1991, Karr \& Chu 2000) but also extended to insects (Benthic IBI or B-IBI, Kerans \& Karr 1994). A multimetric index is composed of multiple independent metrics (e.g., percent omnivores, species richness of cyprinids, percent individuals with deformities). An alternative approach, known as Rivpacs (Wright 1995) and Ausrivas (Norris \& Hawkins 2000), builds a multivariate model relating habitat conditions to the biota (typically, to the $\log$ abundances of the more common species) for reference conditions, and then predicts the biota expected at test sites. Deviation of the observed biota from that expected under the model is a measure of impact.

To anticipate an issue discussed in more detail below, biological metrics have been constructed with the intent that they reflect multiple stressors. While their value is beyond dispute, bioassessment methods that integrate many causes of stream degradation may be of questionable effectiveness in diagnosing the causes of degradation.

\section{Linkages between Landscape and Biota}

A growing number of studies establish a significant relationship between some landscape metric and some biological metric. Roth et al. (1996) found a decline in the Index of Biotic Integrity for fish as the amount of agricultural land increased in southeastern Michigan. Similarly, the IBI increased with increasing forest cover in a number of Wisconsin rivers (Wang 1997). In urban areas of Washington State, Morely and Karr (2002) observed strong declines in a benthic IBI with increasing urban land cover. Stewart et al. (2001) observed changes in both fish and invertebrate metrics in response to a number of landscape metrics for agricultural catchments of Wisconsin.

Such studies clearly support the utility of catchment-scale studies linking landscape to stream condition. However, limitations in this approach also are becoming apparent, and help to identify a series of future challenges for this emerging field.

\section{Six Challenges to the Catchment Approach}

\section{Linear vs. non-linear relationships}

Figure 1 portrays a hypothetical and simple relationship between some stressor and a biological response variable, for example, a biotic index versus urbanization. A non-linear response is intriguing, because it indicates a threshold. This is useful for managers, because it suggests a critical region of sensitivity of the ecosystem to stress, and therefore helps to set acceptable limits. In contrast, a linear response suggests that each increment of stress results in an increment of biological degradation. If a linear response is observed, managers must set limits based on whatever biological index is used, and be able to argue that the index should not be 


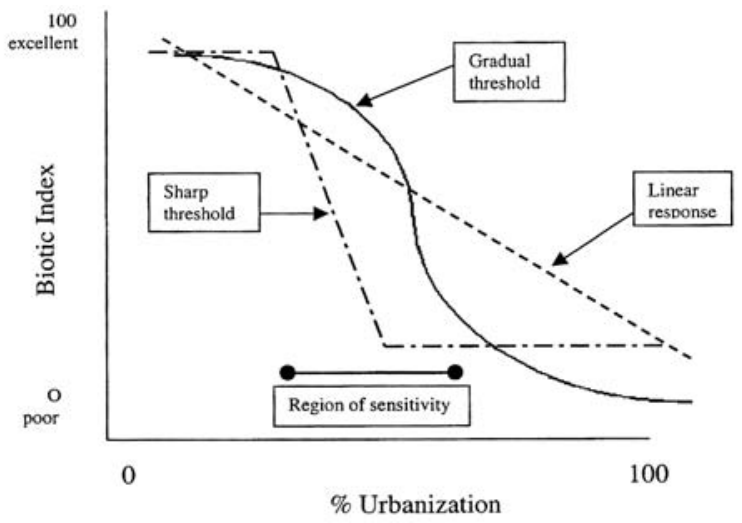

Figure 1. An idealized stressor-response relationship contrasting linear and non-linear responses of a biotic index to increasing levels of a stressor, such as urbanization. A non-linear response identifies a region of sensitivity or threshold where the biological community undergoes rapid transition to a degraded state. Relación idealizada presión-respuesta contrastando las respuestas linear y no linear de un índice biótico frente al incremento del nivel de una presión, como es el caso de la urbanización. Una respuesta no linear se corresponde con una zona de sensibilidad o umbral donde la comunidad biológica sufre una rápida transición a un estado degradado.

permitted to fall below some level, such as $60 \%$ of its maximum.

Several studies of urban ecosystems in North America suggest that stream condition responds non-linearly to urbanization, and that serious degradation takes place approximately in the range of $15-25 \%$ urban land cover or impervious surface (Schueler 1994, Wang et al. 2000, Stranko and Rodney 2001). In a study of 47 small streams in southeastern Wisconsin, USA, several fish metrics showed a non-linear response to increasing percent imperviousness in the catchment, with a threshold near $10 \%$ (Wang et al. 2000). In contrast, Morley and Karr (2002) found a reasonably linear response of a benthic invertebrate IBI to increasing urbanization, which in their study areas in Washington State, USA, varied from approximately 10 to $60 \%$ imperviousness.

\section{Legacy effects}

The legacies of past human impacts often are present and may not be widely recognized. In the USA, with its relatively young history of human development, legacy effects for all kinds of ecosystems are receiving increasing attention (Foster et al. 2003). Some legacy effects are apparent, such as artificially straightened stream channels. However, others may not be readily detected, such as the substantial loss of large pool habitat due to sedimentation from past road-building and logging, which has been documented in streams of the Pacific Northwest USA by re-surveying streams where pool survey records from 1934 and 1946 were available for comparison (Gregory \& Bisson 1997). The floating of $\operatorname{logs}$ to market is believed to have caused extensive channel and bank scouring, and intensive agriculture near stream margins has allowed greater channel migration than has occurred in undisturbed sites (Jacobsen \& Pugh 1997). It may be incorrect to attribute degraded stream conditions to present land use, when legacy effects may be of greater importance.

Harding et al. (1998) provide a compelling example of what they termed the "ghost of land use past". They found that catchment land use from nearly 50 years earlier was a better predictor of present-day biological diversity in streams in the southeastern USA, whereas riparian and catchment land use in the 1990's were comparatively poor indicators. In essence, forested streams on land that had been farmed still resembled present-day agricultural streams, apparently due to the legacy of sediments from earlier farming. Historical human impacts likely override natural factors in determining the fluvial landscapes along most European rivers (Décamps et al 1988). For example, present day riparian forest communities reflect the long history of navigation in and agriculture along the River Garonne, France, whose floodplain forest is no longer subject to successional resets induced by inundation.

\section{Spatial scale}

The question of spatial scale is one of the most challenging and fundamental issues facing stream ecologists. This issue is informed by a large 
literature, including studies of longitudinal zonation (Illies \& Botosaneanu 1963), the River Continuum Concept (Vannote et al. 1980), and spatial hierarchies including stream order (Horton 1945) and habitat models (Frissell et al. 1986, Hawkins et al. 1993). The habitat to landscape hierarchy developed by Frissell and colleagues is useful when considering how multiple human impacts affect streams at various spatial scales (Allan et al. 1997). For example, the presence or absence of trees in the riparian can affect microhabitat conditions by providing shade, root wads, and maintaining bank stability. Vegetation over the scale of hundred of meters is relevant to the supply of coarse particulate organic matter, and shade extending over several kilometers can moderate water temperature (Abell \& Allan 2002). However, flow pathways, which can affect channel scouring, and nutrient inputs, which can influence biological production, likely are governed by the integrated effects of land use over much longer riparian corridors, and perhaps the larger catchment as well.

A number of recent studies have examined the relationships between biological metrics and land use/cover quantified at different spatial scales, and particularly stream buffer vs. catchment-wide land cover information. Such studies usually find a variety of significant relationships at each spatial scale. In southeastern Michigan, Roth et al. (1996) reported stronger correlations of an IBI for fish with catchment rather than riparian land cover, although a later study by Lammert and Allan (1999) found stronger relationships with riparian than catchment land use. Lammert and Allan suggested that these different outcomes might be explained by differences in study design, as the sites in the former study included markedly different catchment conditions, whereas the latter study selected multiple sites in only a few catchments.

The recent increase in studies that assess landscape influences at multiple spatial scales suggest that significant relationships may be detected at both local and larger scales, depending on the context of the study and the variables selected. Stewart et al. (2001) compared site, reach, segment and catchmentscale measurements, and compared riparian buffer vs. catchment-wide measures for 38 agricultural streams in Wisconsin, USA. At the catchment scale, percent forest influenced fish diversity, intolerant fish, and some invertebrate metrics. Fragmentation of riparian vegetation also affected the invertebrate metrics, and at the reach scale, substrate embeddedness with fine sediments also affected invertebrate metrics. The authors remarked that the high degree of intercorrelation of environmental factors made it difficult to draw conclusions from correlations alone.

\section{Multiple Stressors, Unidentified Mechanisms}

As the study by Stewart et al. (2001) exemplifies, the environmental stressors that affect stream ecosystems are multiple and interacting, and as a consequence, inferring causation can be difficult. Indeed, the majority of studies linking landscape variables to stream status provide at best a weak explanation of the likely intervening mechanisms between such complex variables as, for example, agricultural land in the catchment and a biological metric. In their thorough review of streams in the urban landscape, Paul \& Meyer (2001) concluded that the lack of mechanistic studies was a major shortcoming. Few of the studies they reviewed analyzed whether physical habitat, water quality, or food web disturbances were the cause of observed biological degradation in urban streams.

Figure 2 illustrates a number of possible pathways whereby landscape metrics of disturbance or stress may result in biological impact and be quantified as a correlation between a biological metric and a landscape metric. An impact may be due to multiple causes, or one may dominate. While it would be very useful to know if the biota are stressed by chemical factors or altered habitat, even this level of understanding falls short of a detailed mechanistic understanding. 


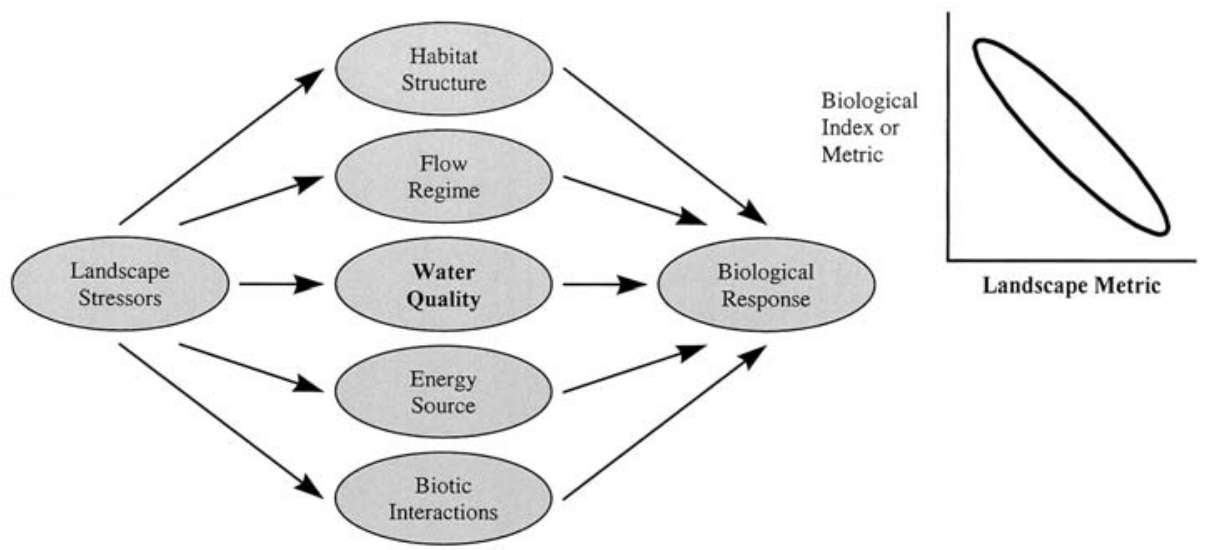

Figure 2. Multiple pathways may account for a significant relationship between a landscape metric and a biotic response metric. Múltiples caminos pueden explicar una relación significativa entre una métrica del paisaje y una métrica de la respuesta biótica.

\section{Covariance of Natural and Anthropogenic Gradients}

Studies of the relationship between land cover and stream condition often have the goal of identifying human impacts. Because natural and anthropogenic gradients both can be discerned at the landscape scale, and often covary (e.g., agricultural land may be less steep and rocky than forested land), it is imperative that some effort be made to separate what is natural from that which is human-induced. If no quantification of geology and terrain is included, then the variance attributed to anthropogenic effects may be inflated by hidden, natural co-variation. Fitzpatrick et al. (2001) recognized this problem in concluding that the spatial overlap of geological setting with land cover made it difficult to infer probable causation and which spatial scale had the dominant effect on stream response variables.

One potential solution, adopted by Wood \& Allan (2003), is to test landscape stressor variables against stream response variables in a predetermined sequence. Those variables that are considered natural (e.g., geology, slope) are tested first for their ability to predict biological response. If any show a significant relationship to the stream response variables, they are retained, and then anthropogenic metrics (e.g., agriculture in the buffer or urban land in the catch- ment) are tested to determine if they significantly improve the fit. This approach ensures that anthropogenic variables are selected only if their influence is measurable after the natural gradient is accounted for.

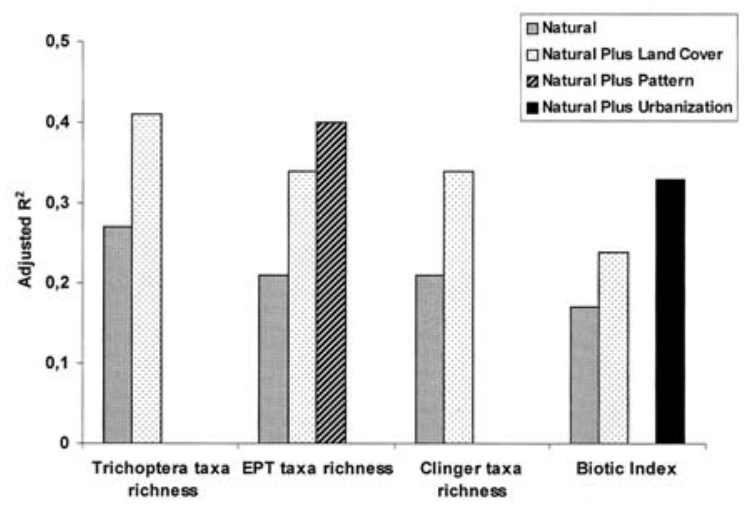

Figure 3. Potential explanatory variables are tested in a planned sequence to ascertain their additional explanatory value. A natural gradient consisting of geology variables explains significant variance in several invertebrate indices, and land cover adds significantly to the fit. Landscape pattern metrics and urbanization are significant additional variables for two of the four indices.Variables potencialmente explicativas son examinadas en una secuencia planificada para averiguar su valor explicativo adicional. Un gradiente natural consistente en variables geológicas explica la varianza significativa en varios índices de invertebrados, y la cubierta del suelo incrementa significativamente el ajuste. Las métricas de patrones del paisaje y de su urbanización son variables adicionales significativas para dos de los cuatro índices. 


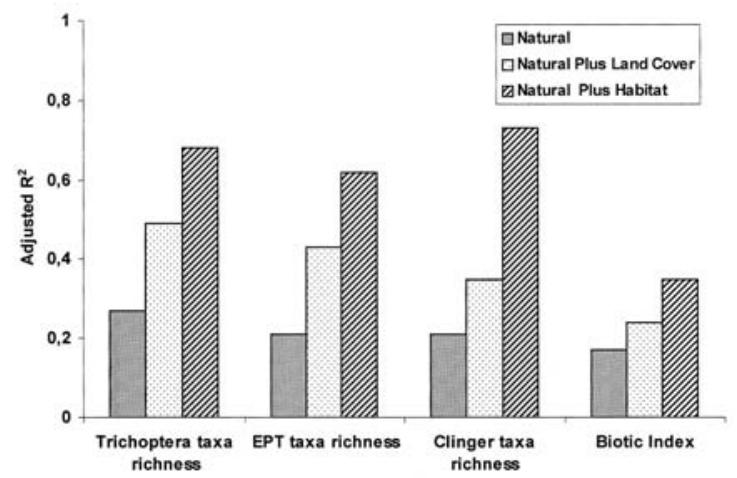

Figure 4. Tested sequentially, the natural gradient, land cover, and in-stream habitat each improve the ability to predict these invertebrate indices, indicating their separate explanatory value (from Wood \& Allan, in prep.). Examinados secuencialmente, el gradiente natural, la cubierta del suelo, y el habitat fluvial, van mejorando la capacidad de predecir estos indices de invertebrados, indicando su valor explicativo separado (según Wood \& Allan, en prep.).

As shown in figure 3, natural variation, including coarse geology and catchment area, explains a significant amount of the variance for several invertebrate indices, and land cover variables explain additional variance. However, with these two suites of variables included in the regression, landscape pattern metrics explain little additional variance, contributing significantly to only one metric. Similarly, urbanization (which combines population density and road density) contributes significantly to only one metric as well.

Another analysis with the same data demonstrates that natural variation, land cover, and instream habitat are each important in explaining the variance in stream biota (Fig. 4). These results indicate that instream habitat and land cover are essentially independent predictors, together explaining a large fraction of the variation (approximately $70 \%$ ) in stream condition as assessed by the three of the invertebrate indices.

\section{Diagnosis}

The preceding discussion makes it abundantly clear that a difference exists between knowing that a system is impaired, and knowing why it is

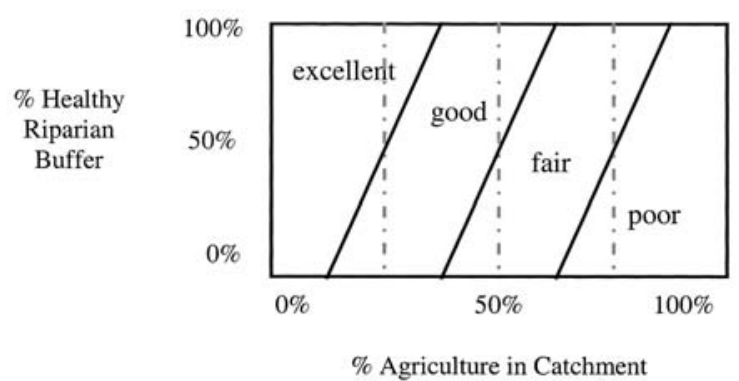

Figure 5. In this hypothetical response space, stream condition is a function of some stressor, such as extent of agricultural activity in the catchment, and some mitigating factor or management practice, such as maintaining a healthy riparian buffer. Note that a stream with (e.g.) $25 \%$ agricultural land in the catchment might be in excellent or good biological condition, depending upon the mitigating effect of riparian management (from Wood \& Allan, in prep.). En este espacio de respuesta hipotético, el estado del río es una función de alguna presión, como la extensión de la actividad agrícola en la cuenca, y de algún factor mitigante o práctica de gestión, como mantener una zona riparia saludable. Ver cómo un río con (ej.) el $25 \%$ de terreno agrícola en su cuenca puede encontrarse en una condición biológica buena o excelente, dependiendo de el efecto mitigante de la gestión riparia (según Word \& Allan, en prep.).

impaired. Metrics of biological condition are designed to detect deviation from reference or best available condition, and most of them do so reasonably well. However, for management action to occur, it is necessary also to diagnose the cause or causes of impairment. Non-linear relationships, multiple causation, lack of mechanistic understanding, and legacy effects together limit our ability to diagnose cause and prescribe corrective action. To use a medical analogy, we may be quite sure our patient is sick, but not know why.

In practice the solution to this dilemma may be straightforward. Causation may be established based on professional judgement, or additional data such as laboratory toxicity tests or in situ confinement of animals may provide convincing evidence of the source of stress. However, this is one area where further study holds much promise.

An improved understanding of the relationship between stressors and mitigating management actions could improve our understanding 
of the potential for beneficial activities to compensate for harmful impacts. As figure 5 illustrates with a hypothetical response space for some biological indicator, a stream's biological condition indeed may decline as the extent of agriculture increases, but a healthy riparian or other best management practice can partially mitigate. For example, at $25 \%$ agricultural land in the catchment a stream may be rated as excellent or only good, at $50 \%$ good or fair, at $75 \%$ fair or poor. Steedman (1988) provides an example where the effects of urbanization vary, depending upon the amount of forested land in the riparian. Such an analysis implies that management can improve stream condition, although within constraints due to existing land use or other stressors that are impractical to alter greatly.

\section{CONCLUSIONS}

A substantial and rapidly growing literature addresses the impacts of changing land use on rivers, largely by coupling land-use data derived using Geographic Information Systems to data assessing the status of streams and rivers. This research is motivated by questions both fundamental and applied. An improved understanding of the basic mechanisms linking rivers to the landscapes through which they run is critical to the design of conservation plans, for management and restoration, and to improve our ability to perform bioassessments. However, more progress is needed in developing mechanistic explanations for statistical associations between land use and stream condition. Lotic ecology has a long history of viewing rivers in a landscape context, and provides a solid foundation in stream ecology research within which to interpret the impacts of changing land-use on stream ecosystems. Future research that combines a basic understanding of the pathways whereby human alteration of landscapes influences river condition can serve the dual function of advancing both management and understanding of lotic ecosystems.

\section{ACKNOWLEDGEMENTS}

I thank the organizers of the Spanish Limnology XI Congress and Iberian Limnology III Congress, held in Madrid in June 2002, for the opportunity to present these views. In particular I thank Manuel Toro and Ramón Peña for their hospitality. I thank Rebecca Cifaldi and Dana Infante for their editorial assistance, and Mahya Wood for her assistance and insights in working through the tiered regression analysis approach. Discussions with members of the TALU workgroup (US EPA) contributed to the development of the ideas presented here.

\section{BIBLIOGRAPHY}

ABELL, R. \& J. D. ALLAN. 2002. Riparian shade and stream temperature in an agricultural catchment, Michigan, USA. Verh. Internat. Verein. Limnol., 28: 1-6.

ALBA-TERCEDOR, J. y A. SÁNCHEZ-ORTEGA. 1988. Un método rápido y simple para evaluar la calidad biológica de las aguas corrientes basado en el de Hellawell (1978). Limnetica, 4: 51-56

ALLAN, J. D., D. L. ERICKSON \& J. FAY. 1997. The influence of catchment land use on stream integrity across multiple spatial scales. Freshwat. Biol., 37: 149-161.

ALLAN, J. D. \& A. S. FLECKER. 1993. Biodiversity conservation in running waters. BioScience, 43: 32-43.

ALLAN, J. D. \& L. B. JOHNSON. 1997. Catchmentscale analysis of aquatic ecosystems. Freshwat. Biol., 37: 107-111.

BENKE, A. C. 1990. A perspective on America's vanishing streams. J. N. Am. Benthol. Soc., 9: 77-88.

BRYCE, S. A., D. P. LARSEN, R. M. HUGHES, \& P. R. KAUFMANN. 1999. Assessing relative risks to aquatic ecosystems: A mid-Appalachian case study. Journal of the American Water Research Association, 35(1): 23-36.

DÉCAMPS, H., M. FORTUNÉ, F. GAZELLE \& G. PAUTOU. 1988. Historical influence of man on the riparian dynamics of a fluvial landscape. Landscape Ecology, 1(3): 163-173.

FITZPATRICK, F. A., B. C. SCUDDER, B. N. LENZ \& D. J. SULLIVAN. 2001. Effects of multi-scale environmental characteristics on agri- 
cultural stream biota in eastern Wisconsin. Journal of the American Water Resources Association, 37(6): 1489-1507.

FORMAN, R. T. T. \& M. GODRON. 1986. Landscape Ecology. New York, John Wiley and Sons.

FOSTER, D., F. SWANSON, J. ABER, I. BURKE, N. BROKAW, D. TILMAN \& A. KNAPP. 2003. The importance of land-use legacies to ecology and conservation. BioScience, 53: 77-88.

FRISSELL, C. A., W. J. LISS, C. E. WARREN \& M. D. HURLEY. 1986. A hierarchical framework for stream habitat classification: Viewing streams in a watershed context. Environmental Management, 10(2): 199-214.

GREGORY, S. V. \& P. A. BISSON. 1997. Degradation and loss of anadromous salmonid habitat in the Pacific Northwest. In: Pacific Salmon and their Ecosystems. D. J. STOUDER, P. A. BISSON, \& R. J. NAIMAN (eds.): 277-314. New York, Chapman \& Hall.

GREGORY, S. V., F. J. SWANSON, W. A. MCKEE \& K. W. CUMMINS. 1991. An ecosystem perspective of riparian zones: Focus on links between land and water. BioScience, 41(8): 540-551.

HARDING, J. S., E. F. BENFIELD, P. V. BOLSTAD, G. S. HELFMAN \& E. B. D. JONES. 1998. Stream biodiversity: The ghost of land use past. Proceedings of the National Academy of Sciences U.S.A., 95: 14843-14847.

HAWKINS, C. J., J. L. KERSCHNER, P. A. BISON, M. D. BRYANT, L. M. DECKER, S. V. GREGORY, D. A. MCCULlOUGH, C. K. POVERTON, G. H. REEVES, R. J. STEEDMAN \& M. K. YOUNG. 1993. A hierarchical approach to classifying stream habitat features. Fisheries, 18: 311.

HELLAWELL, J. M. 1986. Biological indicators of freshwater pollution and environmental management. Elsevier Applied Science Publishers, London.

HILSENHOFF, W. L. 1987. An improved biotic index of organic stream pollution. Great Lakes Entomologist, 10: 31-39.

HORTON, R. E. 1945. Erosional development of streams and their drainage basins: Hydrophysical approach to quantitative morphology. Bulletin of the Geological Society of America, 56: 275-350.

HYNES, H. B. N. 1975. The stream and its valley. Verh. Internat. Verein. Limnol., 19: 1-15.

ILLIES, J. \& L. BOTOSANEANU. 1963. Problemes et methodes de la classification et de la zonation ecologicque des eaux courantes, considerees surtout du point du vue faunistique. Mitt. Int. Ver. Theor. Ang. Limnol., 12: 1-57.

JACOBSON, R. B. \& A. L. PUGH. 1997. Riparian vegetation controls on the spatial pattern of stream-channel instability, Little Piney Creek, Missouri. U.S. Geological Survey Water-Supply paper 2494.

KARR, J. R. 1991. Biological integrity: A longneglected aspect of water resource management. Ecological Applications, 1(1): 66-84.

KARR, J. R., J. D. ALLAN \& A. C. BENKE. 2000. River conservation in the United States and Canada. In: Global Perspectives on River Conservation: Science, Policy, and Practice. P. J. Boon, B. R. Davies \& G. E. Petts (eds.): 3-39. New York, John Wiley and Sons.

KARR, J. R. \& E. W. CHU. 2000. Sustaining living rivers. Hydrobiologia, 422/423: 1-14.

KARR, J. R. \& E. W. CHU. 1999. Restoring life in running waters. Island Press, Washington DC.

KERANS, B. L \& J. R. KARR. 1994. A benthic index of biotic integrity (B-IBI) for rivers of the Tennessee Valley. Ecological Applications, 4: 768785.

LAMMERT, M. \& J. D. ALLAN. 1999. Assessing biotic integrity of streams: Effects of scale in measuring the influence of land use/cover on habitat structure on fish and macroinvertebrates. Environmental Management, 23(2): 257-270.

LOWRANCE, R., L. S. ALTIER, J. D. NEWBOLD, R. R. SCHNABEL \& P. M. GROFFMAN. 1997. Water quality functions of riparian forest buffers in Chesapeake Bay watersheds. Environmental Management, 21(5): 687-712.

MASTER, L. L., S. R. FLACK \& B. A. STEIN. (eds.). 1998. Rivers of life: Critical watersheds for protecting freshwater biodiversity. The Nature Conservancy, Arlington, Virginia.

MCGARIGAL, K. \& B. J. MARKS. 1994. FRAGSTATS: Spatial pattern analysis program for quantifying landscape structure. Corvallis, OR.

MORLEY, S. A. \& J. R. KARR. 2002. Assessing and restoring the health of urban streams in the Puget Sound Basin. Conservation Biology, 16(6): 14981509.

NAIMAN, R. J. \& H. DECAMPS. (eds.). 1990. The ecology and management of aquatic-terrestrial ecotones. Man and the Biosphere Series number 4. Paris: UNESCO; Carnforth, England: Parthenon. 
NAIMAN, R. J., J. J. MAGNUSON, D. M. MCKNIGHT \& J. A. STANFORD. 1995. The freshwater imperative. Island Press, Washington, DC.

NORRIS, R. H. \& C. P. HAWKINS. 2000. Monitoring river health. Hydrobiologia, 435: 5-17.

PAUL, M. J. \& J. L. MEYER. 2001. Streams in the urban landscape. Annual Review of Ecology and Systematics, 32: 333-365.

POFF, N. L., J. D. ALLAN, M. A. PALMER, D. D. HART, B. RICHTER, A. H. ARTHINGTON, K. H. ROGERS, J. L. MEYER \& J. A. STANFORD. 2003. River flows and water wars? Emerging science for environmental decision-making. Frontiers in Ecology and the Environment, 1: 298306.

ROTH, N. E., J. D. ALLAN \& D. E. ERICKSON. 1996. Landscape influences on stream biotic integrity assessed at multiple spatial scales. Landscape Ecology, 11: 141-156.

SCHUELER, T. R. 1994. The importance of imperviousness. Watershed Protection Techniques, 1: 100-111.

SCHUFT, M. J. 1999. Development of landscape metrics for characterizing riparian-stream networks. Photogrammatic Engineering \& Remote Sensing, 65: 1157-1167.

STEEDMAN, R. J. 1988. Modification and assessment of an index of biotic integrity to quantify stream quality in Southern Ontario. Canadian Journal of Fisheries and Aquatic Sciences, 45: 492-501.

STEWART, J. S., L. Z. WANG, J. LYONS, J. A. HORWATICH \& R. BANNERMAN. 2001. Influences of watershed, riparian-corridor, and reach-scale characteristics on aquatic biota in agricultural watersheds. Journal of the American Water Resources Association, 37(6): 1475-1487.

STRANKO, S. \& W. RODNEY. 2001. Habitat quality and biological integrity assessment of freshwater streams in the Saint Mary's River Watershed. Maryland Department of Natural Resources: 27.

VANNOTE, R. L., W. G. MINSHALL, K. W. CUMMINS, J. R. SEDELL \& C. E. CUSHING 1980. The river continuum concept. Can. J. Fish. Aquat. Sci., 37(37): 130-137.

WANG, L., J. LYONS \& P. KANEHL. 1998. Development and evaluation of a habitat rating system for low-gradient Wisconsin streams. $N$. Am. Fish. Manag., 18(4): 477-485.

WANG, L., J. LYONS, P. KANEHL \& R. GATTI 1997. Influence of watershed land use on habitat quality and biotic integrity in Wisconsin streams. Fisheries, 22(6): 6-12.

WANG, L., J. LYONS, P. KANEHL, R. BANNERMAN \& E. EMMONS. 2000. Watershed urbanization and changes in fish communities in southeastern Wisconsin streams. Journal of the American Water Resources Association, 36(5): 1173-1189.

WOOD, M. G. S. 2002. The Influence of Land Cover and In-Stream Habitat on the Biological Condition of Streams in Southeastern Michigan: A Comparison of Indices. Masters Thesis, the University of Michigan.

WRIGHT, J. F. 1995. Development and use of a system for predicting the macroinvertebrate fauna in flowing waters. Australian Journal of Ecology, 20: 181-197. 
